Revista de Metalurgia 52(1)

January-March 2016, e063

ISSN-L: 0034-8570

doi: http://dx.doi.org/10.3989/revmetalm.063

\title{
Leaching performance of imidazolium based ionic liquids in the presence of hydrogen peroxide for recovery of metals from brass waste
}

\author{
Ayfer Kilicarslan $^{\bowtie}$, Muhlis N. Saridede \\ Yildiz Technical University, Department of Metallurgical and Materials \\ Engineering (Davutpasa Campus), Esenler, 34210 Istanbul, Turkey \\ Corresponding author: kilicarslanayfer@gmail.com
}

Submitted: 27 October 2015; Accepted: 26 December 2015; Available On-line: 16 February 2016

\begin{abstract}
The application of ionic liquids (ILs), 1-methylimidazolium hydrogen sulfate ( $\mathrm{HmimHSO}_{4}$ ), 1-ethyl-3-methylimidazolium hydrogen sulfate $\left(\mathrm{EmimHSO}_{4}\right)$ and 1-butyl-3-methylimidazolium chloride $(\mathrm{BmimCl})$ as leaching agents was investigated in the leaching of copper and zinc from brass waste in the presence of an oxidant, hydrogen peroxide $\left(\mathrm{H}_{2} \mathrm{O}_{2}\right)$. Factors that affect copper and zinc dissolution rates such as ionic liquid concentration, time and temperature were investigated. The results indicated that zinc was dissolved in

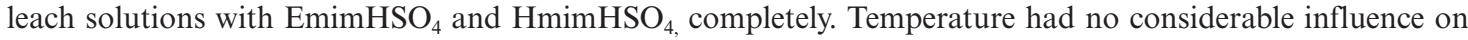
copper dissolution rate whilst the rate increased with decreasing IL concentration. In the $\mathrm{EmimHSO}_{4}$ system, higher copper recoveries were achieved with $40 \%$ and $60 \%$ IL concentrations compared with IL concentrations of $20 \%$ and $80 \%$ at $40{ }^{\circ} \mathrm{C}$ leaching temperature. Copper dissolution rates decreased with EmimHSO$_{4}$ concentration at $60{ }^{\circ} \mathrm{C}$ and $80{ }^{\circ} \mathrm{C}$ in the following order; $40 \%>20 \%>60 \%>80 \%$. On the other hand the leaching system with $\mathrm{BmimCl}$ generally resulted in poor extractions of copper and zinc.
\end{abstract}

KEYWORDS: Hydrogen peroxide; Ionic liquid; Leach; Metal; Recovery; Waste

Citation / Cómo citar este artículo: Kilicarslan, A., Saridede, M.N. (2016) "Leaching performance of imidazolium based ionic liquids in the presence of hydrogen peroxide for recovery of metals from brass waste". Rev. Metal. 52(1):e063. doi: http://dx.doi.org/10.3989/revmetalm.063.

RESUMEN: Rendimiento de la lixiviación con líquidos iónicos basados en imidazolio en presencia de peróxido de hidrógeno para la recuperación de metales a partir de residuos de latón. Este trabajo investiga el uso de líquidos iónicos (LIs), hidrogenosulfato de 1-metillimidazolio $\left(\mathrm{HmimHSO}_{4}\right)$, hidrogenosulfato de 1-etil-3-metilimidazolio $\left(\right.$ EmimHSO $\left._{4}\right)$ y cloruro de 1-butil-1-metilimidazolio $(\mathrm{BmimCl})$, como agentes de lixiviación de cobre y zinc a partir de residuos de latón en presencia de un oxidante, peróxido de hidrógeno $\left(\mathrm{H}_{2} \mathrm{O}_{2}\right)$. Se estudiaron distintos factores que afectan a la velocidad de disolución del cobre y el zinc, como la concentración del líquido iónico, el tiempo y la temperatura. Los resultados indican que el zinc se disuelve completamente en las disoluciones que contienen $\mathrm{EmimHSO}_{4}$ y $\mathrm{HmimHSO}_{4}$. La temperatura no tiene un efecto significativo en la velocidad de disolución del cobre, mientras que dicha velocidad aumenta al disminuir la concentración del líquido iónico. En los sistemas que contienen $\mathrm{EmimHSO}_{4}$, los mejores resultados de recuperación del cobre se obtuvieron con concentraciones del $20 \%$ y el $80 \%$ de LI, a una temperatura de lixiviación de $40{ }^{\circ} \mathrm{C}$. Sin embargo, la velocidad de disolución del cobre disminuye con la concentración de $\mathrm{EmimHSO}_{4}$ en los sistemas a $60{ }^{\circ} \mathrm{C}$ y $80{ }^{\circ} \mathrm{C}$ en el siguiente orden: $40 \%>20 \%>60 \%>80 \%$. Por otro lado, el sistema de lixiviación con BmimCl generalmente dio como resultado extracciones pobres tanto de cobre como de zinc.

PALABRAS CLAVE: Líquido iónico; Lixiviación; Metal; Peróxido de hidrógeno; Recuperación; Residuos

Copyright: (C) 2016 CSIC. This is an open-access article distributed under the terms of the Creative Commons Attribution-Non Commercial (by-nc) Spain 3.0 License. 


\section{INTRODUCTION}

Wastes which occur during brass production are considered to be significant copper and zinc resources because of their high copper and zinc content (Nesbitt and Xue, 1995; Welter and Revet, 2001; Kahvecioglu et al., 2003) Some previous researchers (Abdel Basir and Rabah, 1999; Timur et al., 2000; Ahmed et al., 2012; Kilicarslan and Saridede, 2015a) have proposed hydrometallurgical recycling processes for the recovery of metals from brass waste using the conventional acid leaching process.

Recently, ionic liquids (ILs) have been focused on as alternative solvents for the sustainable dissolution, extraction and separation of metal ions (McCluskey et al., 2002; Dandan and Kyung, 2010). ILs are organic salts composed of two components, anions and cations and they generally have low melting points $\left(<100{ }^{\circ} \mathrm{C}\right)$. It is possible to design an IL with the desired specifications to meet the requirement of a specific process (Earle and Seddon, 2000). Their unique properties such as low vapor pressure, non-flammability, wide liquid range and thermal stability to solubilize a wide range of solutes including metal salts and complexes make them attractive for hydrometallurgical applications. Especially, their ability to dissolve a variety of components at low temperatures makes the ILs promising and green alternatives to the traditional aqueous acid/alkaline solutions used in hydrometallurgical processes (Tian et al., 2010).

Up to now, ILs have been studied as solvents in various leaching systems for the dissolution of transition metals, gold and silver from their concentrates. McCluskey et al., (2002) studied the IL 1-butyl3-methyl-imidazolium tetrafluoroborate $\left(\mathrm{BmimBF}_{4}\right)$ for leaching of chalcopyrite and found that after 8 hours, $90 \%$ of copper extraction was achieved at $100{ }^{\circ} \mathrm{C}$. Whitehead et al., (2004) studied the extraction of gold and silver from ores by 1-butyl-3methyl-imidazolium hydrogen sulfate IL leaching $\left(\mathrm{BmimHSO}_{4}\right)$ in the presence of iron (III) sulfate as an oxidant and thiourea. $87 \%$ of gold, and $\geq 60 \%$ of silver recovery were achieved with the relatively selective dissolution with regard to the other metals $(\mathrm{Cu}$, $\mathrm{Zn}, \mathrm{Pb}$ and $\mathrm{Fe}$ ) present in the concentrate. Dong et al., (2009) investigated the leaching of chalcopyrite using $\mathrm{BmimHSO}_{4}$ as leaching solution and reported that the leaching efficiency of copper increased from $51.8 \%$ to $87.8 \%$ when the IL concentration in the leaching solution increased from $10 \%$ (v/v) to $100 \%$. Apart from these, dissolution of copper from waste printed circuit boards using the same IL $\left(\mathrm{BmimHSO}_{4}\right)$ has been studied by Huang et al., (2014) and they reached almost $100 \%$ of copper recovery in $80 \%(\mathrm{v} / \mathrm{v})$ of the IL concentration with the addition of $10 \mathrm{~mL}$ of hydrogen peroxide.

In this study, the leaching of brass waste for the recovery of copper and zinc was investigated by using various ionic liquids, 1-methylimidazolium hydrogen sulfate $\left(\mathrm{HmimHSO}_{4}\right)$, 1-ethyl-3-methylimidazolium hydrogen sulfate (EmimHSO ${ }_{4}$ ) and 1-butyl-3-methylimidazolium chloride $(\mathrm{BmimCl})$. The leaching characteristics and the leaching rate of the metals were examined as a function of time. In addition, temperature and IL concentration, as affecting factors, were investigated in the leaching processes.

\section{MATERIALS AND METHODS}

\subsection{Raw materials}

Brass waste used in the present study was obtained from Ozer Metal Company (Tekirdag, Turkey). In the plant, brass melting slag is treated to separate coarse (metallic values) and fine fractions as shown in Fig. 1. Coarse fraction is recharged to the melting furnace while the remaining part of the slag (brass ash) is stored for retreatment via a pyro/hydrometallurgical process. Total sample $(2 \mathrm{~kg})$ taken from the company was split into representative subsamples using a rotary cone sample divider for characterization and dissolution tests. ICP-OES method was used to determine the chemical analyses of the brass waste sample and the results are presented in Table 1. Moreover, mineralogical compounds were determined by X-ray diffraction analysis (XRD) and the results are given in Fig. 2. The results of the chemical and mineralogical analyses showed that the waste is rich in metallic copper, copper oxide, and zinc oxide. Also it contains calcium and silicium compounds.

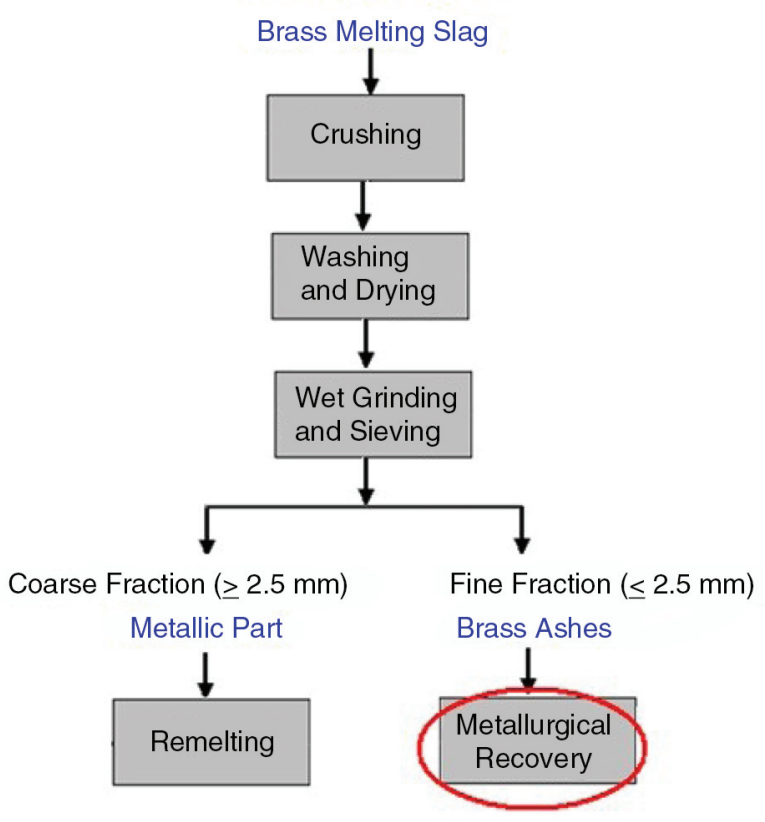

FIGURE 1. Schematic presentation of brass melting slag treatment procedure. 
TABLe 1. Chemical composition

of brass waste sample (wt, $\%)$

\begin{tabular}{lcccccccc}
\hline $\mathbf{Z n}$ & $\mathbf{C u}$ & $\mathbf{C a}$ & $\mathbf{A l}$ & $\mathbf{M g}$ & $\mathbf{N a}$ & $\mathbf{C a}$ & $\mathbf{S}$ & $\mathbf{S i}$ \\
\hline 53.92 & 22.36 & 5.81 & 1.84 & 0.10 & 0.30 & 0.95 & 0.32 & 3.51
\end{tabular}

\subsection{Ionic liquids}

In order to perform the leaching tests of brass waste in imidazolium based ionic liquids, 1-methylimidazolium hydrogen sulfate $\left(\mathrm{HmimHSO}_{4}\right)$, 1-ethyl3-methylimidazolium hydrogen sulfate $\left(\right.$ EmimHSO$\left._{4}\right)$ and 1-butyl-3-methylimidazolium chloride (BmimCl) were used because of their water soluble character which is crucial for the leaching process. The structures of the ionic liquids purchased from Sigma Aldrich (Germany) are shown in Fig. 3.

Both ILs, $\mathrm{HmimHSO}_{4}$ and $\mathrm{EmimHSO}_{4}$ contain hydrogen sulfate anions but $\mathrm{BmimCl}$ contains a chloride anion. They all have acidic characters. $\mathrm{EmimHSO}_{4}$ is in liquid form but $\mathrm{HmimHSO}_{4}$ and $\mathrm{BmimCl}$ present as solid at room temperature and their melting points are $39^{\circ} \mathrm{C}$ and $70^{\circ} \mathrm{C}$, respectively

\subsection{Dissolution tests}

A closed glass reactor with $250 \mathrm{~mL}$ capacity was used in the leaching tests. It was placed in a water bath on a magnetic stirrer. Ionic liquids 1-methylimidazolium hydrogen sulfate $\left(\mathrm{HmimHSO}_{4}\right)$, 1-ethyl-3-methylimidazolium hydrogen sulfate $\left(\mathrm{EmimHSO}_{4}\right)$ and 1-butyl-3-methylimidazolium chloride $(\mathrm{BmimCl})$ and their aqueous solutions were used as leaching solutions in $200 \mathrm{~mL}$ volume. Distilled water was used to prepare IL aqueous solutions. Hydrogen peroxide $\left(\mathrm{H}_{2} \mathrm{O}_{2}\right)$ was added as the oxidizing agent at constant volume $20 \%(\mathrm{v} / \mathrm{v})$ into all leaching solutions to enhance particularly copper dissolution (Kilicarslan et al., 2014). When the solution reached

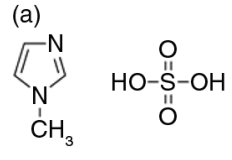<smiles>CCn1cc[n+](C)c1OS(=O)(=O)O</smiles><smiles></smiles>

Figure 3. Chemical structure of: (a) $\mathrm{HmimSO}_{4}$, (b) $\mathrm{EmimHSO}_{4}$ and (c) BmimCl.

the desired temperature, $20 \mathrm{~g}$ of brass waste was poured into the reactor. This amount of waste in $200 \mathrm{~mL}$ solution provides $1 / 100$ solid liquid ratio. Sample solutions were taken during the leaching test periodically and then solutions were separated from the residues by filtration to obtain clean solutions for the analysis of metals $(\mathrm{Cu}$ and $\mathrm{Zn})$. Metal contents of solutions were determined using atomic absorption spectrometer (AAS). The effects of temperature and IL concentration on copper and zinc dissolutions were investigated.

\section{RESULTS AND DISCUSSION}

\section{1. $\mathrm{HmimHSO}_{4}$ leaching}

\subsubsection{Zinc Dissolution}

The effect of the $\mathrm{HmimHSO}_{4}$ ionic liquid concentration on zinc dissolution for temperatures of 40, 60 and $80{ }^{\circ} \mathrm{C}$ is shown in Fig. 4. In 20 minutes, all zinc in the waste was dissolved, due to higher solubility of $\mathrm{ZnO}$ in the ionic liquid solution for 20 , 40, 60, and $80 \%$ concentrations of $\mathrm{HmimHSO}_{4}$ at $40^{\circ} \mathrm{C}$. It is evident that the ionic liquid concentration did not influence the zinc recovery rate significantly at moderate temperatures. At $60{ }^{\circ} \mathrm{C}$ and $80{ }^{\circ} \mathrm{C}$, the amount of dissolved zinc in the $\mathrm{HmimHSO}_{4}$ solution was negligible when the mixture of $80 \%$ $\mathrm{HmimHSO}_{4}(\mathrm{v} / \mathrm{v})$ and $20 \% \mathrm{H}_{2} \mathrm{O}_{2}$ (v/v) was used as leach solution. The reason for this limited zinc solubility is no additional water used. It can be said that

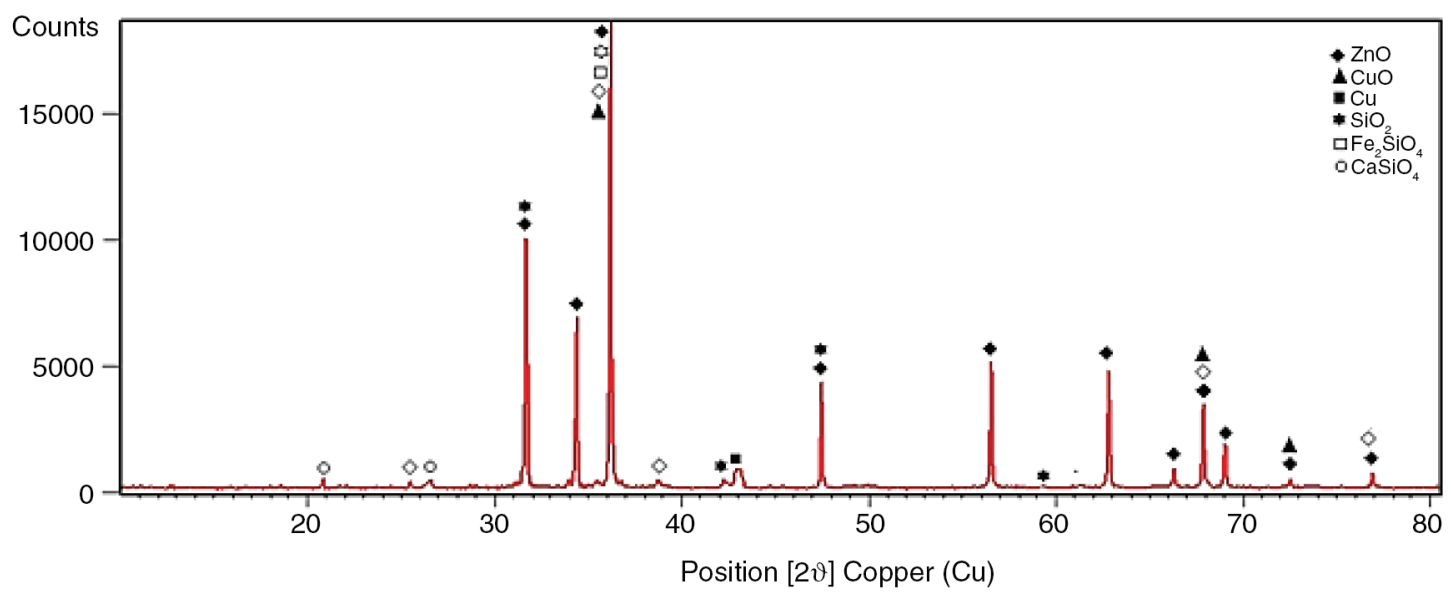

FIGURE 2. XRD pattern of waste sample. 

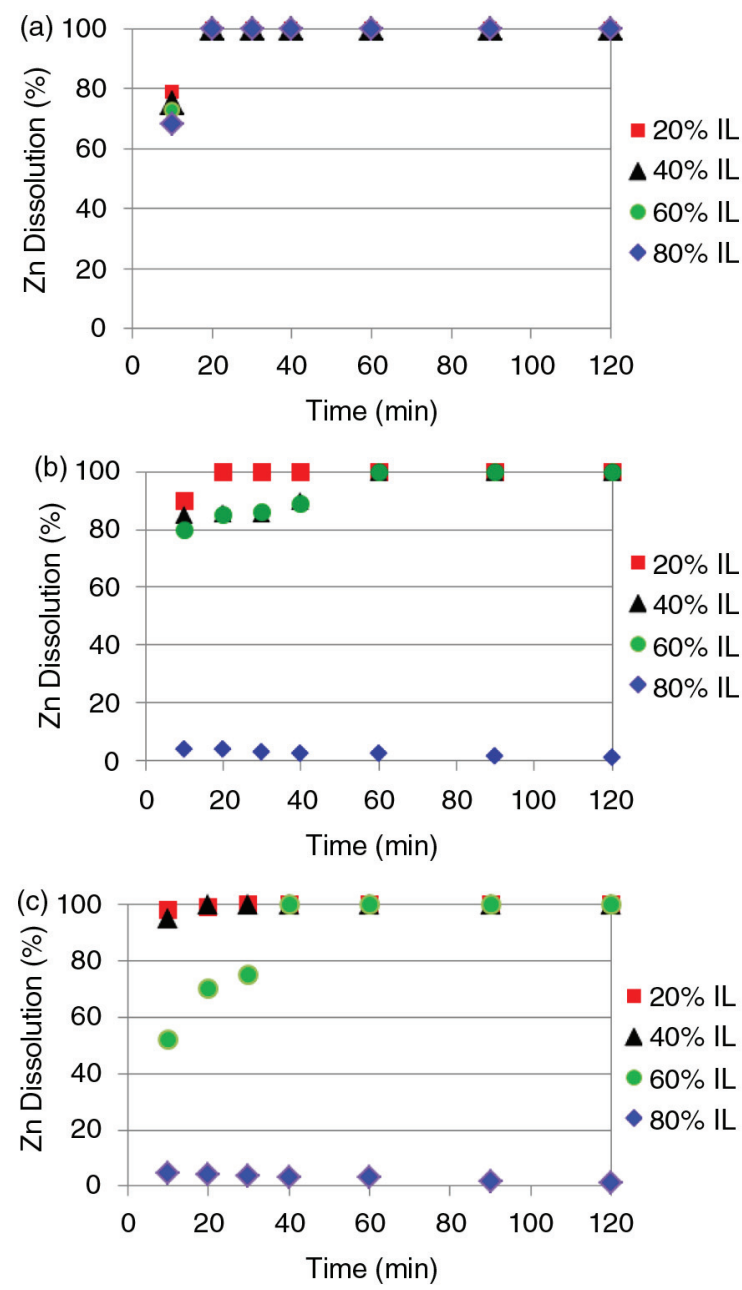

FiguRE 4. Effect of temperature and $\mathrm{HmimHSO}_{4}$ concentration on zinc dissolution: (a) $40^{\circ} \mathrm{C}$, (b) $60^{\circ} \mathrm{C}$ and (c) $80^{\circ} \mathrm{C}$.

the extraction of zinc in aqueous $\mathrm{HmimHSO}_{4}$ system is significantly higher than in the non-aqueous system with higher $\mathrm{HmimHSO}_{4}$ concentrations.

All the zinc was dissolved in concentration of $20 \%$ IL (v/v) after 20 minutes leaching time. However, 60 minutes were needed for $40 \%$ and $60 \%$ IL (v/v) concentration at $60{ }^{\circ} \mathrm{C}$ and 20 minutes for $40 \%$ and 40 minutes for $60 \%$ IL (v/v) concentration at $80^{\circ} \mathrm{C}$ to dissolve all zinc in the waste. Zinc dissolution rate increased significantly from $2.20 \%$ to $100 \%$ when the ionic liquid concentration decreased from $80 \%$ to any other concentration after 60 minutes at $60{ }^{\circ} \mathrm{C}$. Likewise, it increased remarkably from $3.20 \%$ to $100 \%$ with the same IL concentrations at $80^{\circ} \mathrm{C}$ after 40 minutes.

\subsubsection{Copper Dissolution}

Figure $5 \mathrm{a}$ shows the effect of $\mathrm{HmimHSO}_{4}$ ionic liquid concentration on copper recovery rates at $40^{\circ} \mathrm{C}$ as a function of leaching time. The copper
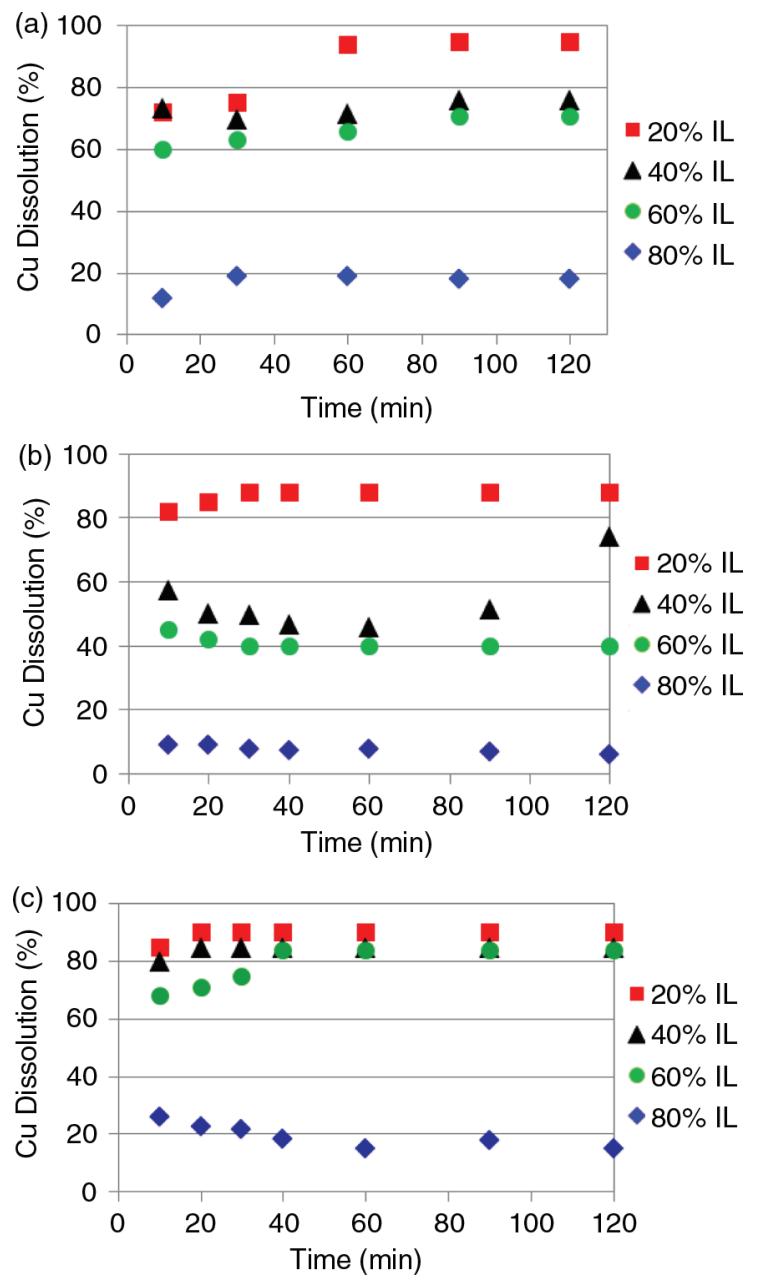

Figure 5. Effect of temperature and $\mathrm{HmimHSO}_{4}$ concentration on copper dissolution: (a) $40^{\circ} \mathrm{C}$, (b) $60^{\circ} \mathrm{C}$ and (c) $80^{\circ} \mathrm{C}$.

recovery rate increases considerably with decreasing ionic liquid concentration from 80 to $20 \%(\mathrm{v} / \mathrm{v})$. When ionic liquid concentration was $80 \%(\mathrm{v} / \mathrm{v})$, copper recovery rate was about $20 \%$ at the end of total leaching time. Moreover, a rapid increase was observed with decreasing ionic liquid concentration between $60 \%$ and $20 \%(\mathrm{v} / \mathrm{v})$. Copper dissolution increased from $17.98 \%$ to $70.69 \%$ with decreasing of the ionic liquid concentration from $80 \%$ to $60 \%(\mathrm{v} / \mathrm{v})$ in 120 minutes. A smaller difference was observed between $60 \%$ and $40 \%$ ionic liquid concentrations during leaching time. But, importantly, copper dissolution increased from $76.16 \%$ to $95 \%$ with decreasing ionic liquid concentration from $40 \%$ to $20 \%(\mathrm{v} / \mathrm{v})$.

The effect of $\mathrm{HmimHSO}_{4}$ concentration on the copper recovery at $60^{\circ} \mathrm{C}$ and $80^{\circ} \mathrm{C}$ is given in Fig. $5 \mathrm{~b}$ and $\mathrm{c}$ respectively. The extraction of copper at the temperature of $60{ }^{\circ} \mathrm{C}$ and $80{ }^{\circ} \mathrm{C}$ showed a similar trend as in Fig. 5a, that is the copper recovery rate increased remarkably as the $\mathrm{HmimHSO}_{4}$ 
concentration decreased from 80 to $20 \%$ for both leaching temperatures. After 60 minutes, increasing the leaching time has no effect on the dissolution rate of zinc and copper for each temperature and each IL concentration.

The ionic liquid, $\mathrm{HmimHSO}_{4}$ acted like an acid in aqueous solution, and the hydrogen peroxide played an important role as an oxidant in the study. The oxygen coming from the decomposition of hydrogen peroxide reacts with metallic copper to form cupric oxide, which can easily react with ionic liquid to form cupric compounds or dissolved copper.

\subsection{EmimHSO 4 leaching}

\subsubsection{Zinc Dissolution}

Dissolution of zinc in the presence of hydrogen peroxide $20 \%(\mathrm{v} / \mathrm{v})$ was investigated in various concentrations of 1-ethyl-3-methylimidazolium hydrogen sulfate $\left(\mathrm{EmimHSO}_{4}\right)$ ionic liquid at temperatures of 40,60 and $80^{\circ} \mathrm{C}$. Zinc dissolution was
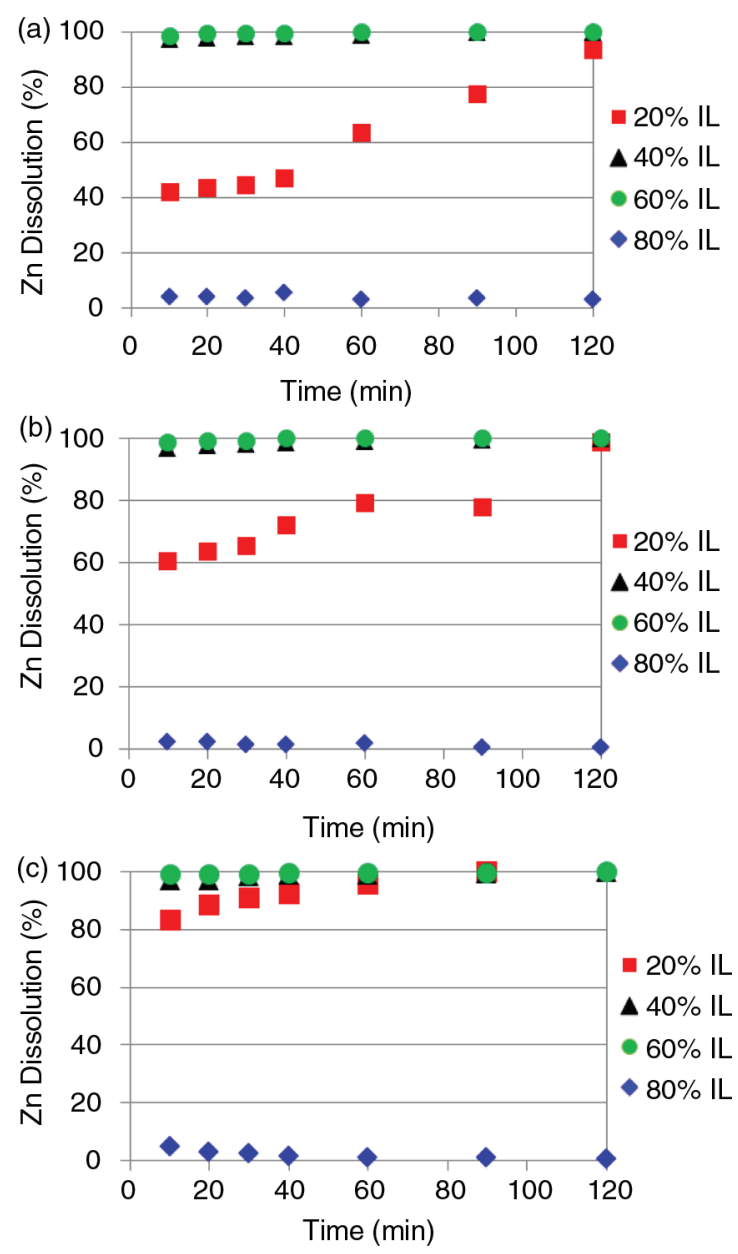

FiguRE 6. Effect of temperature and $\mathrm{EmimHSO}_{4}$ concentration on zinc dissolution: (a) $40^{\circ} \mathrm{C}$, (b) $60^{\circ} \mathrm{C}$ and (c) $80^{\circ} \mathrm{C}$. completed at all temperatures in 10 minutes when 40 and $60 \%(\mathrm{v} / \mathrm{v})$ IL concentrations were used (Fig. 6). Dissolution rate values in 20\% (v/v) IL concentration increased significantly with increasing temperature in the first 10 minutes giving $41.93 \%, 60.23 \%$ and $83.23 \%$ dissolution rates at 40,60 and $80{ }^{\circ} \mathrm{C}$, respectively. Furthermore, dissolution of zinc in $20 \%(\mathrm{v} / \mathrm{v})$ IL concentration showed a general increment with increasing leaching time at studied temperatures achieving 100\% dissolution at the end.

On the other hand, it is notable that the $80 \% \mathrm{IL}$ did not give any satisfactory results for zinc dissolution at any temperature or time. Because this solution only consists of $80 \%$ IL and $20 \%$ oxidant and no water, while solutions of 20,40 and $60 \%$ IL contain calculated amounts of water with oxidant addition. When EmimHSO $\mathrm{H}_{4}$ concentration of 20\%, 40\%, 60\% (v/v) in aqueous solutions with $20 \% \mathrm{H}_{2} \mathrm{O}_{2}$ (oxidant) is present, the hydrogen sulfate anion can dissociate releasing $\mathrm{H}^{+}$ions and hence the EmimHSO $\mathrm{H}_{4}$ plays the role of an acid as reported in a previous study for ionic liquid $\mathrm{BmimHSO}_{4}$ by Whitehead et al., (2007). In the case of $80 \%(\mathrm{v} / \mathrm{v}) \mathrm{EmimHSO}_{4}$, the dissociation capability of the hydrogen sulphate anion and ability to act as an acid is reduced because proton hydration cannot occur in the mixture of ionic liquid and oxidant. Consequently, zinc dissolution is higher in $40 \%$ and $60 \%$ IL concentrations compared with ionic liquid rich $(80 \% \mathrm{IL})$ and water rich $(20 \% \mathrm{IL})$ media.

\subsubsection{Copper Dissolution}

The influence of temperature, EmimHSO${ }_{4}$ concentration and leaching time on copper dissolution in the brass waste is given in Fig. 7. Higher copper recoveries were achieved in $40 \%$ and $60 \%$ IL (v/v) concentrations admixed with water and oxidant compared with IL concentrations of $20 \%$ and $80 \%$ (v/v) at $40{ }^{\circ} \mathrm{C}$ leaching temperature. Maximum copper recovery was obtained as $48.82 \%$ in $40 \%$ IL (v/v) at the end of 120 minutes. $20 \%$ and $80 \%$ IL concentrations gave very limited copper dissolution and no marked changes were observed with increasing time during 120 minutes under the studied conditions (Fig. 7a).

The dissolution of copper at the temperature of $60{ }^{\circ} \mathrm{C}$ and $80^{\circ} \mathrm{C}$ showed a similar trend (Fig. 5b and $\mathrm{c}$ ) in that the copper dissolution rates increased with $\mathrm{EmimHSO}_{4}$ concentration in the following order: $40 \%>20 \%>60 \%>80 \%$. Maximum copper recovery rates were $51.53 \%$ and $52.27 \%$ for $60{ }^{\circ} \mathrm{C}$ and $80{ }^{\circ} \mathrm{C}$ leaching temperatures, respectively at $40 \%$ IL aqueous solution. Especially, 80\% IL (v/v) mixed with $20 \% \mathrm{H}_{2} \mathrm{O}_{2}$ was unsuccessful as leachant compared to the other mixtures in $60{ }^{\circ} \mathrm{C}$ and $80^{\circ} \mathrm{C}$ though higher dissolution rates were obtained than at $40{ }^{\circ} \mathrm{C}$. This is the result of a lack of additional water in the initial leach solution. Changing of dissolution rates with time was in the very narrow range. 

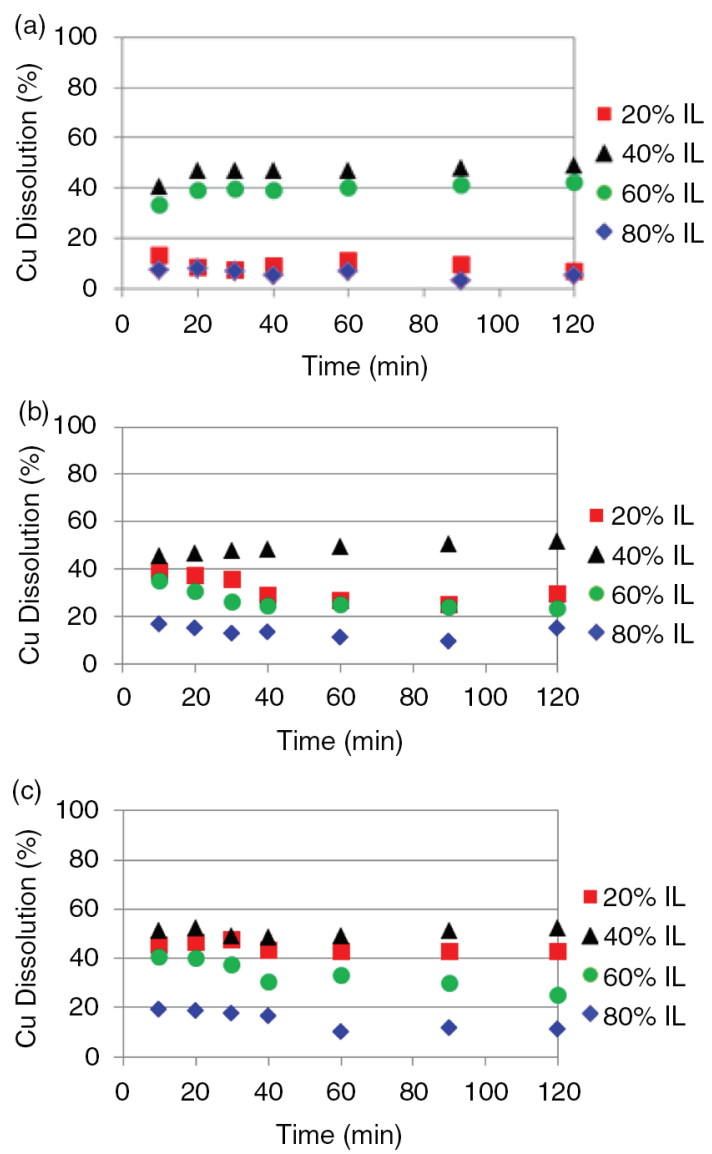

FIGURE 7. Effect of temperature and $\mathrm{EmimHSO}_{4}$ concentration on copper dissolution: (a) $40^{\circ} \mathrm{C}$, (b) $60^{\circ} \mathrm{C}$ and (c) $80^{\circ} \mathrm{C}$.

\subsection{BmimCl dissolution}

\subsubsection{Zinc Dissolution}

As shown in Fig. 8, zinc has only partial solubility in various $\mathrm{BmimCl}$ concentrations admixed with water and oxidant at 40,60 and $80^{\circ} \mathrm{C}$ leaching temperatures. Increase in the $\mathrm{BmimCl}$ concentration resulted in a serious decrease in the dissolution of zinc at both 40 and $60{ }^{\circ} \mathrm{C}$ (Fig. 8a and b). However, when the temperature was increased to $80{ }^{\circ} \mathrm{C}$, then higher $\mathrm{BmimCl}$ concentrations provided higher zinc dissolution yields (Fig. 8c). While the maximum zinc dissolution rate was $33.38 \%$ in $20 \%$ IL (v/v) at $40{ }^{\circ} \mathrm{C}$, it was $38.84 \%$ at $80 \%$ IL (v/v) at $80{ }^{\circ} \mathrm{C}$. Furthermore, a notable decrease in the dissolution rates of zinc with time was observed during the leaching process for all concentrations and temperatures.

\subsubsection{Copper Dissolution}

Figure 9 reveals that the extraction of copper in the $\mathrm{BmimCl}$ system remained under $10 \%$. Negligible copper solubility in this system is due to the
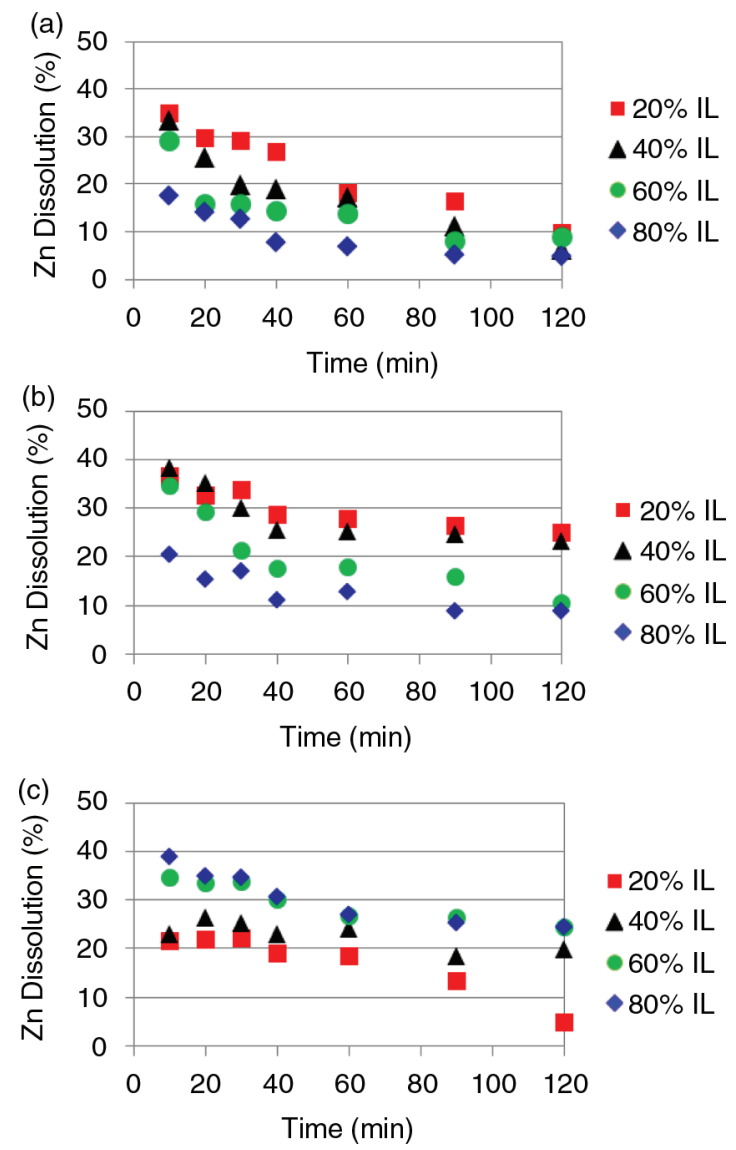

Figure 8. Effect of temperature and $\mathrm{BmimCl}$ concentration on zinc dissolution: (a) $40^{\circ} \mathrm{C}$, (b) $60^{\circ} \mathrm{C}$ and (c) $80^{\circ} \mathrm{C}$.

insolubility of copper ion in chloride media in contrast to the sulfate systems. Changing IL concentration in water did not lead to higher dissolution yields of zinc. Increasing of temperature from 20 to $80^{\circ} \mathrm{C}$ did not improve the results either. Also, copper dissolution rates decreased with increasing leaching time. At the end of the test time of 120 minutes, there was no difference among the dissolution rates between 40 and $60{ }^{\circ} \mathrm{C}$ for any concentration especially in longer leaching times. Hence, use of BmimCl with $\mathrm{H}_{2} \mathrm{O}_{2}$ as leaching media is not ideal to dissolve copper and zinc. It is clear from a comparison of the $\mathrm{HmimHSO}_{4}, \mathrm{EmimHSO}_{4}$ and $\mathrm{BmimCl}$ leaching systems that, although the hydrogen sulfate systems give high extractions of copper and zinc, it is far less for the chloride system. The systems containing $\mathrm{HSO}_{4}$ are clearly better than the $\mathrm{Cl}$ system and has high potential for recovery of copper and zinc efficiently.

The applications of ionic liquids are available for the electrodeposition of metals from leach liquors after solid-liquid separation (Whitehead et al., 2004; Kilicarslan and Saridede, 2015b). Electrodeposition of metal present in an ionic liquid leach liquor may 

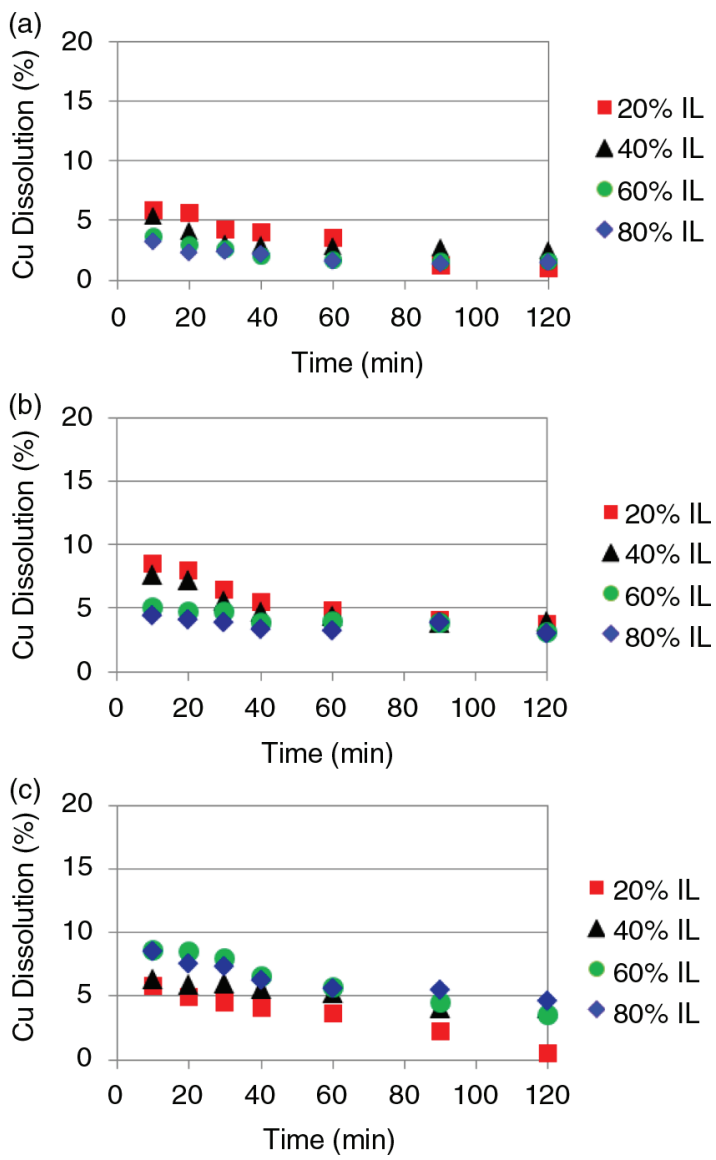

FIGURE 9. Effect of temperature and $\mathrm{BmimCl}$ concentration on copper dissolution: (a) $40^{\circ} \mathrm{C}$, (b) $60{ }^{\circ} \mathrm{C}$ and (c) $80{ }^{\circ} \mathrm{C}$.

also be considered an advantages method due to the ability of reusing the non-volatile stripped ionic liquid solution for further leach cycles which makes the process cost effectiveness and less harmful to the environment.

\section{CONCLUSIONS}

In the present work, dissolution of copper and zinc in industrial brass ash was investigated using ionic liquids (ILs); 1-butyl-3-methylimidazolium chloride (BmimCl), 1-ethyl-3-methylimidazolium hydrogen sulfate $\left(\right.$ Emim $\left.\mathrm{HSO}_{4}\right)$, and 1-methylimidazolium hydrogen sulfate $\left(\mathrm{HmimHSO}_{4}\right)$ as leaching media with hydrogen peroxide as oxidant. $100 \% \mathrm{Zn}$ recovery was achieved in $\mathrm{EmimHSO}_{4}$ and $\mathrm{HmimHSO}_{4}$ leaching systems. Furthermore, $\mathrm{HmimHSO}_{4}$ was found to be the most efficient ionic liquid for recovery of copper among the studied ionic liquids and the maximum copper dissolution rate is $95 \%$ under the following conditions: $20 \%(\mathrm{v} / \mathrm{v}) \mathrm{HmimHSO}_{4}$, $40{ }^{\circ} \mathrm{C}$ and 2 hours. However, leaching systems with $\mathrm{BmimCl}$ generally resulted in poor extractions of copper and zinc.

\section{ACKNOWLEDGMENTS}

The authors would like to express their sincere thanks to the Scientific and Technological Research Council of Turkey (TUBITAK) (Project No: 113M241) for the support and to Ozer Metal Company, Turkey for kindly providing brass waste.

\section{REFERENCES}

Abdel Basir, S.M., Rabah, M.A. (1999). Hydrometallurgical recovery of metal values from brass melting slag. Hydrometallurgy 53 (1), 31-44. http://dx.doi.org/10.1016/S0304386X(99)00030-4.

Ahmed, I.M., Nayl, A.A., Daoud, J.A. (2012). Leaching and recovery of zinc and copper from brass slag by sulfuric acid. J. Saudi Chem. Soc. (In press). http://dx.doi.org/10.1016/j. jscs.2012.11.003.

Dandan, H., Kyung, H.R. (2010). Recent applications of ionic liquids in separation technology. Molecules 15 (4), 2405-2426. http://dx.doi.org/10.3390/molecules15042405.

Dong, T., Hua, Y., Zhang, O., Zhou, D. (2009). Leaching of chalcopyrite with Brønsted acidic ionic liquid. Hydrometallurgy 99 (1-2), 33-38. http://dx.doi.org/10.1016/j.hydromet. 2009.06.001.

Earle, M.J., Seddon, K.R. (2000). Ionic liquids. Green Solvents for the future. Pure Appl. Chem. 72 (7), 1391-1398. http:// dx.doi.org/10.1351/pac200072071391.

Huang, J., Chen, M., Chen, H., Chen, S., Sun, Q. (2014). Leaching behavior of copper from waste printed circuit boards with Brønsted acidic ionic liquid. Waste Manage. 34 (2), 483-488. http://dx.doi.org/10.1016/j.wasman.2013.10.027.

Kahvecioglu, Ö., Derin, B., Yücel, O. (2003). Carbothermal recovery of zinc from brass ash. Miner. Process. Extr. Metall. Rev. 112 (2), 95-101. http://dx.doi.org/10.1179/037195503225002790.

Kilicarslan, A., Saridede, M.N. (2015a). Recovery of Metallic Values from Brass Waste Using Brønsted Acidic Ionic Liquid as Leachate. JOM 67 (11), 2739-2746. http://dx.doi. org/10.1007/s11837-015-1510-9.

Kilicarslan, A., Saridede, M.N. (2015b). Treatment of industrial brass wastes for the recovery of copper and zinc. Separ. Sci. Technol. 50 (2), 286-291. http://dx.doi.org/10.1080/01 496395.2014.952304

Kilicarslan, A., Saridede, M.N., Stopic, S., Friedrich, B. (2014). Use of ionic liquid in leaching process of brass wastes for copper and zinc recovery. Int. J. Min. Met. Mater. 21 (2), 138-143. http://dx.doi.org/10.1007/s12613-014-0876-y.

McCluskey, A., Lawrance, G.A., Leitch, S.K., Owen, M.P., Hamilton, I.C. (2002). Ionic Liquids Industrial Applications for Green Chemistry, Chapter 16, Ed. American Chemical Society, pp. 199-212. http://dx.doi.org/10.1021/bk-2002-0818. ch016.

Nesbitt, C., Xue, S. (1995). Recycling of base metals from metal wastes of brass foundries in treatment and minimization of heavy metal containing waste, Proceedings of The Minerals, Metals and Materials Society of the AIME, Warrendale, PA, USA.

Tian, G.C., Li, J., Hua, Y.X. (2010). Application of ionic liquids in hydrometallurgy of nonferrous metals. $T$. Nonferrous Metal. Soc. China 20 (3), 513-520. http://dx.doi.org/10.1016/ S1003-6326(09)60171-0.

Timur, S., Gürmen, S., Orhan, G., Arslan, C., Duman, I. (2000). Beneficiation of brass ashes, Proceedings of International Mineral Processing Congress, Rome, Italy.

Welter, J.M., Revet, F. (2001). Method for recycling brass foundry waste, Patent US 6293993 B1, USA

Whitehead, J.A., Lawrence, G.A., McCluskey, A. (2004). Green leaching: recyclable and selective leaching of gold-bearing ore in an ionic liquid. Green Chem. 6 (7), 313-315. http:// dx.doi.org/10.1039/B406148A

Whitehead, J.A., Zhang, J., Pereira, N., McCluskey, A., Lawrance, G.A. (2007). Application of 1-alkyl-3-methyl-imidazolium ionic liquids in the oxidative leaching of sulphidic copper, gold and silver ores. Hydrometallurgy 88 (1-4), 109-120. http://dx.doi.org/10.1016/j.hydromet.2007.03.009. 